\title{
РАЗНОВРСНОСТ И ЗНАЧАЈ ЋОРОВИЋЕВОГ КЬИЖЕВНОГ СВИЈЕТА
}

\author{
(Душко Певуља, Приповједачки свијет Светозара Ћоровића, \\ Центар за српске студије, Бања Лука, 2019)
}

Један од најплоднијих и најразноврснијих српских књижевника с краја 19. и са почетка 20. вијека, утицајни национални првак српског народа из Херцеговине, оснивач српских институција културе, уредник календара и часописа у Мостару, Светозар Ћоровић (1875-1919), данас је највећим дијелом свога књижевног и националног рада скрајнут и маргинализован. Ни по чему то Ћоровић није заслужио, али та непријатна истина говори доста о одсуству дугорочне и систематичне културне и научне стратегије у српском народу читавих стотину година послије пишчевог упокојења, као и једне опште незаинтересованости, научне помодности, нејасне стихије и искривљених стереотипа којима су још увијек оптерећени и којима се руководе поједини истраживачи српске књижевности и културе. Од послова важних за развој националних институција културе међу Србима у Херцеговини, Ћоровић је непосредно учествовао у оснивању српског пјевачког друштва „Гусле“ (крајем 1887), уредио је календар Неретљљанин (1893), а са Атанасијем Шолом и Алексом Шантићем покренуо је и уређивао књижевни часопис Зора (18961901). Ћоровић је био и један од покретача и креатора Пријегледа „Мале библиотеке“ 1902 . године у коме су објављене неке од најрепрезентативнијих књига српске књижевности тога времена.

Изразито активан на књижевном, културном, просвјетитељском и политичком плану, Ћоровић је изградио не само углед међу својим сународницима у Херцеговини и Босни, него и бројне контакте и пријатељске везе са књижевницима и националним дјелатницима широм тадашњих српских простора. Највише је био окренут према Београду, али и Новом Саду, Дубровнику, Сарајеву, Бањој Луци, Цетињу, Задру и Загребу, али и заграничним срединама, попут Беча и Пеште. Дакле, према свим оним срединама у којима су постојали снажни српски књижевни часописи и динамичан књижевни живот. О томе најбоље свједочи његова књига сјећања на драгоцјене савременике, истакнуте српске књижевнике, попут Стевана Сремца, Сима Матавуља, Радоја Домановића, Боре Стан- 
ковића, Петра Кочића, Ива Ћипика и сл. Истинске људске и литерарне симпатије исказао је и у успоменама на хрватског модернистичког лиричара Силвија Страхимира Крањчевића, који му је био професор у другом разреду Трговачке школе у Мостару. Између бројних записа који заслужују да буду запамћени издвајамо чињеницу да је Ћоровић оставио ненадмашно свједочење о томе како је за једну ноћ 1901. године, приликом пишчевог боравка у Мостару, баш у Ћоровићевој кући написана једна од најбољих прича српског језика, „Пилипенда“ Симе Матавуља. Одмах иза тога прича је објављена у часопису Зора, а затим је прештампана у Матавуљевој збирци С мора и с планине (1901). Захваљујући свему томе, Ћоровић је уз неколико својим пријатеља из мостарског књижевног круга, Алексе Шантића и Јована Дучића, прије свега, уздигао град Мостар у ред најважнијих центара српске књижевности на крају 19. и на почетку 20. вијека.

Подсјећамо да се као плодан писац, Ћоровић подједнако досљедно огледао и као приповједач, као романсијер и драмски стваралац, чије је дјело тематски готово искључиво било везано за ужи завичај са градом Мостаром као средиштем умјетничког универзума, али и за непосредно херцеговачко окружење, нарочито за град Невесиње. «Грађе за цртицу, слику, игру, или чак и роман, увијек је имао пред очима: у живом комешању мостарске чаршије, у сјенци њених махала и скривених 'пећина', по башчама и виноградима, на хоризонту херцеговачке земље» (Б. Милановић). Познато је да се као прозаиста Ћоровић непосредно исказао у свим прозним формама, од кратке приче, преко новеле и приповијетке, до приповијести и романа. У почетним годинама књижевног рада оставио је неколико књига кратких прича или цртица, како је обичавао у поднасловима или самим насловима да их ближе одређује: Из Херцеговине (1896), Из Мостара (1898), Из моје домовине (1898), Записии из касабе (1901), Цртице (1901). Кад је ријеч о средњим прозним формама, о новелама и приповијеткама, између осталог оставио је четири књиге приповједака под заједничким насловом У часовима одмора (1903-1910), а затим и збирке са насловима Моји познаници (1909), Комшије (1911) и др. Написао је више приповијести, које се из савремене жанровске перспективе могу посматрати и као кратки романи: Мркоњић (1900), Барон из Дангубище (1901), Женидба Пере Карантана (1902), Јарани (1913), У ћелијама (1919), Брђани (1919) и сл. Најизразити књижевни углед стекао је романима Стојан Мутикаша (1903), Мајчина Султанија (1906), Међу својима (постхумно, 1921). Више пута се окушао и као драмски писац: Ајиша, Зулумћар, Као вихор.

Утицајан као национални трибун, Ћоровић је страдао у Првом свјетском рату, јер су га подозриве а завојевачки и антисрпски настроје- 
не аустријске власти заједно са бројним другим српским родољубима најприје држале као таоца који је био одређен да прати и обезбјеђује војничке транспорте од евентуалних српских напада, иза тога је интерниран у заробљеничке логоре у Бихаћу и Болдогасзони, а затим је био присилно мобилисан и послат на фронт. У затворима је тешко оболио од туберкулозе, тако да је изнемогао, болестан и сасвим изнурен враћен у Мостар 1917. године. Разореног здравља, неизљечиво болестан у Мостару је након повратка са робије успио да напише неколико запажених књижевних дјела. Издвајамо мемоарске Биљешке једног таоца (1919), као и антологијску причу „Посета“. Доживио је крај рата и пропаст Аустрије крајем 1918. године. Познато је из свједочења његове супруге Персе, рођене сестре пјесника Алексе Шантића, да је са великом радошћу дочекао улазак српске војске у Мостар. Пред саму смрт написао је чланак „Морал у нашем друштву“, у коме је са зебњом указао на негативне тенденције присутне у српском друштву, поготово међу мостарским Србима, одмах након ослобођења и завршетка Великог рата. Убрзо након тога Ћоровић се упокојио 17. априла 1919. године.

Правећи резиме на стотину година послије пишчевог упокојења, можемо констатовати да нису била честа издања Ћоровићевих књига, нити су била наглашена интересовања за тумачење његовог књижевног дјела. Повремена издања дјела овога књижевника, као и подсјећање на издање Целокупних дела у седам томова између два свјетска рата која је приредио Стеван Јелача, а објавила „Народна просвета“ у Београду, као и на издање Сабраних дјела у десет томова 1967. године под руководством и у избору Бранка Милановића у едицији „Културно насљеђе“ сарајевске „Свјетлости“, само нас опомињу на неодложне обавезе које српска књижевна наука има према овоме писцу, а које још увијек није урадила. Мислимо прије свега на допуњено и критичко издање свих књижевних и других текстова Светозара Ћоровића, које би на најпотпунији начин показало претходно наглашени значај овога писца у историји српске књижевности и српскога народа у цијелости. Наглашавамо да је о Ћоровићу и његовом дјелу писано у различитим синтезама српске књижевности које су у посљедних стотину и више година урадили Јован Скерлић, Јован Деретић, Предраг Палавестра, Радован Вучковић, Станиша Тутњевић и Горан Максимовић, а оставили су запажене појединачне студије о Ћоровићемо дјелу Јован Дучић, Исидора Секулић, Марко Цар, Бранко Лазаревић, Стеван Јелача, Бранко Милановић, Зденко Лешић, Ранко Поповић и др.

У најновије вријеме, најпотпунија интересовања за дјело и личност Светозара Ћоровића показао је Душко Певуља, професор на Одсјеку за српски језик и књижевност Филолошког факултета у Бањој Луци. При 
томе је на креативан начин објединио двије врсте научних приступа: текстолошки приступ који је резултирао издањима појединих репрезентативних избора из књижевног дјела пишчевог, као и књижевноисторијских и књижевно-интерпретативних приступа који су резултирали и појавом рукописа књижевне студије Приповједачки свијет Светозара Ћоровића који се налази пред нама. Душко Певуља је, најприје, за Антологијску едицију „Десет векова српске књижевности“ Матице српске из Новога Сада приредио репрезентативан избор из обимног опуса Светозара Ћоровића. Затим је за Српско просвјетно и културно друштво „Просвјета“ Републике Српске приредио Изабране приповијетке Светозара Ћоровића, које су објављене крајем 2019. године на Палама. Најзад, за три удружена српска издавача из Србије, Црне Горе и Републике Српске („Штампар Макарије“, „Ободско слово“ и „Херцеговина издаваштво“), уредио је и за штампу припремио Стојана Мутикашу, најпознатији Ћоровићев роман.

Ћоровићев књижевни поступак утемељен је на увјерљивој реалистичко-миметичкој слици свијета, на објективном излагању приче, на прецизном грађењу карактеру јунака, а приповиједање обухвата најзначајније друштвене, моралне и психолошке појаве средине и доба у којем је живио, дјеловао и стварао. Односи се то прије свега на потискивање и нестајање старих времена, на пропадање османлијске власти, долазак аустријских окупационих снага у Босну и Херцеговину, а у складу с тим и на крупне друштвене ломове и промјене, на растакање патријархалног морала, на убрзано социјално раслојавање и пропадање, на немилосрдну корупцију коју су донијели окупаторски чиновници, на сиромашне хамалине и сулудасте просјаке, на трговце и занатлије који су радили са Бечом и Пештом, на ситну варошку интелигенцију коју су предводили попови и учитељи, али највише на онај свакодневни народни живот, чаршијске дужности и навике, сиромаштво и патњу, емоције и страсти, које су се одвијале несметано на мостарској калдрми, у баштама и виноградима, у људским душама и срцима, не осврћући се много на велике друштвене и политичке промјене и нежељене преображаје.

Књижевна студија Приповједачки свијет Светозара Ћоровића сачињена је из укупно пет комплементарних цјелина. Прву цјелину представља уводна студија „Распламсан као пламен“ у којој Душко Певуља указује на корпус истраживања, као и теоријско-методолошке оквире у којима ће се кретати његова интерпретација Ћоровићевог дјела. При томе је показао и веома добре увиде у рецепцију, а као најзначајније тумаче издвојио Богдана Поповића, Милана Ћуковића, Исидору Секулић, Бранка Милановића, Предрага Палавестру, Јована Деретића, Радована Вучковића, Зденка Лешића, Љубицу Томић Ковач, Станишу Тутњевића, 
Ранка Поповића, Горана Максимовића и сл. Певуља се посебно осврнуо и на рецепцију Ћоровићевог дјела учињену од стране истакнутих писаца, попут Јована Дучића, Симе Пандуровића и Иве Андрића и сл. Важну улогу у разумијевању Ћоровићеве приповиједне поетике имале су и књижевне везе овога писца и његовог дјела са српским књижевницима с краја 19. и из почетних деценија 20. вијека, попут Матавуља, Сремца, Домановића, Кочића, Станковића и Ћипика.

У другој цјелини насловљеној „Умијеће приповиједања“ дата је интерпретација репрезентативних приповједака Светозара Ћоровића, међу којима су посебно запажено мјесто заузеле приче из збирки објављених под заједничким насловом У часовима одмора $(1903,1904,1906,1910)$. Певуља указује на три битне карактеристике Ћоровићевих приповједака: на снажну миметичност приказаног свијета, на репрезентативност књижевних јунака, те на изразите новелистичке жанровске ознаке. Прва особина уводи Ћоровићеве приповијетке у аналогије са непосредном стварношћу, највише са Мостаром и Херцеговином, друга на психолошку карактеризацију јунака и препознавање универзалних значења у њиховим индивидуалним особинама и локалним карактерима, а трећа особина на вјештину приповиједања, конструкцију и композицију приче, као и динамичне заплете и неочекиване преокрете у тим заплетима. Наведене особине интерпретативно је успјешно потврдио кроз анализу приповједака „Богојављенска ноћ“, „У ноћи“, „Поп Тандркало“, „Стари Механџија“, „Пендек“, „Под пећинама“, „На визитацији“, „Пријатељи“, „Сан Мехе Фењерџије“" и сл.

У трећој цјелини „Романсијерски свијет“ анализирана су четири романа: Мајчина султанија (1906), Стојан Мутикаша (1907), У ћелијама (1919), као и постхумно објављени роман Међу својима (1921). Певуља је највише пажње с правом посветио анализи два најбоља Ћоровићева романа Мајчине султаније и Стојана Мутикаше. Наглашавамо да скупину „кратких романа“ Светозара Ћоровића, који су често у историјама књижевности жанровски одређивани и као „дуже приповијетке или приповијести“, Певуља није укључио у интерпретативни корпус. Ради се о дјелима: Народюак, Барон из Дангубице, Женидба Пере Карантана, Јарани, Дивљак и Брђани. Овдје посебно помињемо текст Брђана, који је објављен 1919. године, а био је посвећен млађем пишчевом брату и касније познатом историчару српског народа, Владимиру Ћоровићу (18851941).

Певуља наглашава да су у српској науци о књижевности Ћоровићеви романи „прећутани и потцијењени“, изузев Стојана Мутикаше који је присутан у школским лектирама, тако да је аналитички простор за тумачење ових дјела углавном у великој мјери потпуно слободан. Наглаша- 
вамо да је умјесто романа Стојан Мутикаша у чувеној „Нолитовој“ едицији „Српска књижевност - роман“ (у педесет књига), која је објављена 1981. године, уврштен роман Мајчина султанија. Оно што је неопходно нагласити, Ћоровићев наративни поступак из приповједака веома је близак романескном поступку. Међутим, поред наглашене миметичности и драмске конструкције заплета, ипак у романима доминира изнад свега приказивање репрезентативних карактера јунака, који су психолошки веома сложени и омогућили су простор за разноврсно обликовање наративних поступака, у којима се оглашавају главни носиоци пишчевог казивања, као што су јунаци и приповједачи, али и разноликих форми казивања у којима важно мјесто припада унутрашњим монолозима, доживљеном говору, дијалозима јунака, психолошкој нарацији и описима. Отуда се у карактеру овога Ћоровићевог јунака исказују неке веома сложене психолошке собине. На путу животног одрастања, свагдашње борбе и изградње личности, Мутикаша се преображава од сиромашног сеоског дјечака и слуге у богатој трговачкој кући до суровог гуликоже, зеленаша и безосјећајног газде, коме ништа више није свето. Огледа се то у безобзирном односу према сиромашном брату који је остао да живи на селу, према пријатељу из дјетињства, према дјевојци Роси у коју је био заљубљен али чије се љубави одриче када је дошао у прилику да се ожени богатом удовицом, иначе својом газдиницом и да постане насљедник читавог богатства свога газде. На крају Мутикаша израста у мизантропа који скончава потпуно сам, без породице, насљедника и пријатеља.

Други репрезентативни јунак Ћоровићевих романа је Милка из Мајчине султаније. У карактеру те лијепе и размажене газдинске кћери, која се по свему издвајала из патријархалног живота заједнице и пркосила тој заједници, укршта се ћуд надмене заводнице и непромишљене каћиперке, а у суштини трагичне губитнице која ће на крају остати без истинске љубави и постати жртва присилног брака. У том судару немилосрдног живота и личних хтијења јунакиње, касније и несхватљивог јогунства и пркоса који је показивала у браку, те неостварене љубави и погубне љубоморе, можда чак и окнофилије у коју се преображава почетна и неприхваћена љубав њеног нежељеног мужа, Милка скончава трагично на порођају, а на самрти се свети мужу тако што намјерно лаже и пориче да је он био отац њиховом тек рођеном дјетету. У том свом непромишљеном инату не само да се свети мужу, који је освету можда и заслужио, него тиме оставља и трајни жиг сумње да је копиле на животну судбину невиног и тек рођеног дјетета. Отуда је у потпуности утемељен Певуљин закључак да „Мајчина султанија спада у групу најнеобичнијих и најуспјелијих јунакиња Ћоровићевог умјетничког свијета“, а нама се чини и српске књижевности тога времена, по чему је упоредива са нај- 
бољим јунакињама Станковићеве прозе (Коштаном, Ташаном, Софком и др.).

У четвртој цјелини „Ратна проза“ анализирана су Ћоровићева дјела са ратном тематиком, попут антологијске приче „У посети“, приповијести Брђани, те посебно важних мемоарских записа Белешке једног таоца које представљају потресно и аутентично свједочанство пишчевог страдања док је боравио у заробљеништву у аустријским логорима током Првог свјетског рата, али и свједочење о страдању читавог српског народа у годинама ратне окупације Босне и Херцеговине, Србије и Црне Горе. Ту се налази и већ поменути чланак „Морал у нашем друштву“ у коме је һоровић указао на моралну беспризорност појединих богатих трговачких породица из Мостара које су у доба окупације сарађивале, дружиле се и позивале на забаве аустријске официре, а одмах по ослобођењу 1918. године окренули су се српским официрима и постајали блиски са њима, као да никада нису сарађивали са окупаторима. Све је то љутило обичан народ и са згражавањем су гледали на ту врсту моралних суноврата, а поготово су били нерасположени према српским официрима који су у незнању и наивности тако олако прелазили преко свега и прихватали пријатељство оних који то никако нису заслужили.

У петој цјелини „Ка одређивању књижевноисторијског статуса“, Душко Певуља је дао садржајна закључна разматрања у којима је указао на статус Светозара Ћоровића у српској књижевности свога времена, као и мјесто које има у читавој српској књижевности 20. вијека, као и данашњој науци о књижевности и издаваштву. Аналитички закључак Душка Певуља је несумњиво тачан да Светозар Ћоровић у својим најрепрезентативнијим дјелима, која су управо анализирана у овој књижевној студији, припада највећим домашајима цјелокупне српске књижевности.

Посебно наглашавамо да завршну цјелину Певуљине студије, неку врсту истраживачког додатка, обухватају пратећи текстови који су веома важни за разумијевање књижевноисторијског и културноисторијског контекста Ћоровићевог времена и књижевног дјела. Важни су и за разумијевање српског књижевног живота на крају 19. и на почетку 20. вијека, а поготово динамичног књижевног рада у граду Мостару тога времена, које су касније из савремене књижевноисторијске перспективе поједини истраживачи с правом видјели као „мостарско књижевно чудо“ (П. Палавестра, С. Тутњевић, Р. Вучковић, Б. Милановић и сл.). Међу тим пратећим текстовима, које је сачинио Душко Певуља, указујемо на селективну библиографију репрезентативних издања Ћоровићевих дјела, затим на селективни преглед најзначајније литературе о Ћоровићевом дјелу у склопу синтетичких прегледа цјелокупне српске књижевности, као и појединачних студија написаних о Ћоровићевом дјелу. На крају 
рукописа дата је исцрпна хронологија живота и рада Светозара Ћоровића са лијепим увидима у књижевноисторијске и биографске изворе посвећене овоме драгоцјеном писцу српске књижевности.

Књижевна студија Приповједачки свијет Светозара Ћоровића, аутора Душка Певуље, представља иновативан и креативан приступ разноврсном дјелу овога писца. Из тога су проистекли добри савремени увиди, тумачења и вредновања, који ће без сумње изнова подстаћи читалачка и научна интересовања за дјело и личност Светозара Ћоровића. Све то допринијеће новим тумачењима, синтезама, вредновањима, као и издањима овога неправедно скрајнутог, а несумњиво великог писца српске књижевности.

Горан М. Максимовић ${ }^{1}$

Одсек за српску књижевност Филозофски факултет Универзитета у Нишу Ћирила и Методија 2; 1800 Ниш goran.maksimovic@filfak.ni.ac.rs

${ }^{1}$ goran.maksimovic@filfak.ni.ac.rs 